\title{
Sistem Informasi Online berbasis Aplikasi Mobile (SAMPADE) untuk Pelayanan Pajak Daerah Kota Malang
}

\author{
Rizki Yudhi Dewantara \\ Jurusan Administrasi Bisnis, Fakultas Ilmu Administrasi, \\ Universitas Brawijaya, J1.MT. Haryono 169, Malang, 65122, Indonesia \\ riskyudhi@ub.ac.id
}

\begin{abstract}
Abstrak
Kemudahan pelayanan pembayaran dan pelaporan pajak oleh wajib pajak dalam melaksanakan kewajiban perpajakannya akan mampu membantu pemerintah dalam memenuhi target pendapatan negara dari sektor pajak. BP2D Kota Malang adalah salah satu organisasi pemerintah yang berupaya menyelenggarakan kemudahan perpajakan bagi wajib pajak di kota Malang. Kemudahan tersebut diwujudkan dengan menyelenggarakan sistem informasi berbasis mobile SAMPADE yang khusus untuk pajak daerah. Sistem baru ini dihadapkan dengan kendala yang muncul dalam penerapannya, paper ini berupaya mengindetifikasi kendala atas penerapan sistem informasi yang baru saja di implementasikan. Penelitian menggunakan pendekatan kualitatif deskriptif. Analisis penelitian didasarkan pada kualitas sistem, kualitas informasi dan kualitas pelayanan. Hasil penelitian menunjukkan bahwa sistem ini belum sukses diimplementasikan karena kegagalan dalam mewujudkan kualitas sistem dan kualitas informasinya. Simpulan dari paper ini yaitu pentingnya proyek pembuatan dan standarisasi implementasi sistem informasi adalah mutlak diperlukan untuk menjamin sistem yang handal dan adanya keberlanjutan sistem di masa depan sehingga dapat dimanfaatkan secara maksimal.
\end{abstract}

Kata kunci: implementasi sistem, sistem online, kualitas sistem, aplikasi mobile, pelayanan pajak.

\section{Pendahuluan}

Pemungutan pajak daerah di kota malang adalah kurang optimal, hali ini dapat dilihat dari rasio perbedaan antara jumlah pegawai pajak dengan jumlah wajib pajaknya. Reformasi perpajakan yang dilakukan oleh Direktorat Jenderal Pajak (DJP) menekankan pada pemanfaatan teknologi informasi (TI) yang berfungsi untuk mendukung sistem administrasi perpajakan. Wujud dari reformasi perpajakan di bidang administrasi yaitu pengembangan sistem administrasi berbasis teknologi informasi, dalam hal ini teknologi yang digunakan untuk mengolah data, termasuk memproses, mendapatkan, menyusun, menyimpan, memanipulasi data dalam berbagai cara untuk menghasilkan informasi yang berkualitas dalam hal pelayanan pajak Pelayan pajak yaitu informasi yang relevan, akurat dan tepat waktu, yang digunakan untuk keperluan pelaporan pajak, penggalian informasi perpajakan dan juga untuk pengambilan keputusan. Terdapat 3 peran utama sistem informasi dalam organisasi yaitu; 1) Mendukung proses bisnis dan operasional seperti keuangan contohnya akuntansi sampai dengan hal pemasaran yaitu penelusuran pesanan pelanggan, sistem informasi menyediakan dukungan bagi manajemen dalam operasi/kegiatan organisasi dan mendukung pengambilan keputusan; 2. Dapat mengkombinasikan informasi untuk membantu manajer menjalankan menjalankan bisnis dengan lebih baik, informasi yang sama dapat membantu mengidentifikasikan pola tertentu seperti kecenderungan dan untuk mengevaluasi kegiatan bisnis seperti hasil mengamati kembali keputusan sebelumnya. 3) Mendukung strategi untuk keunggulan kompetitif, Sistem informasi yang dirancang untuk membantu pencapaian sasaran strategis organisasi yang menyelenggarakan proses bisnis untuk dapat menciptakan keunggulan. Kota Malang merupakan salah satu daerah di Provinsi Jawa Timur yang telah menggunakan sistem informasi teknologi berbasis elektronik dalam pembayaran dan pelaporan pajak daerahnya. Penerapan sistem berbasis elektronik di Kota Malang didasari Peraturan Pemerintah Kota Malang No. 
91 Tahun 2010. Peraturan ini tentang Jenis Pajak Daerah yang dipungut berdasarkan Penetapan Kepala Daerah atau dibayar Sendiri oleh Wajib Pajak, serta terdapat beberapa jenis pajak daerah yang menggunakan sistem menghitung pajak sendiri (MPS) dan yang masih perlu penanganan khusus. Pajak daerah ini terutama pada pajak hotel, pajak restoran, pajak hiburan dan pajak parkir. MPS adalah sistem pemungutan pajak secara self assessment pada pajak daerah, dan untuk membantu Wajib Pajak dalam mencari informasi terkini tentang perpajakan daerah, maka pemerintah Kota Malang dan Badan Pelayanan Pajak Daerah (BP2D) Kota Malang menyelenggarakan aplikasi mobile dengan nama Sistem Aplikasi Mobile Pajak Daerah (SAMPADE). Sistem ini merupakan perwujudan dari reformasi administrasi perpajakan dalam rangka mewujudkan good governance dan melengkapi sistem pembayaran online dengan e-Tax.

Giap (2011) menyatakan peran penggunan teknologi informasi di bagian pemerintahan mulai dari mengolah data administrasi dan tata usaha, pelayanan masyarakat (public service), pengolahan dan dokumentasi data penduduk, perencanaan, statistika, pengambilan keputusan, dan lain-lain seperti halnya untuk perpajakan. Peran TI menurut Muttaqien dan Kusmayadi (2009) adalah membicarakan informasi yang tidak lepas dari teknologi populer yaitu IT (Information of Technology). Pembicaran TI menyebut adanya ketersediaan teknologi informasi, data yang dapat dikelola dengan mudah, cepat, dan akurat berkat kecanggihan komputer saat ini. Dengan adanya perangkat lunak aplikasi, data tersebut dapat diubah menjadi informasi dan bahkan pengetahuan yang berguna bagi pihak yang berkepentingan. Proses penghimpunan, pengelolaan, dan evaluasi data merupakan pekerjaan yang sangat rumit, peran komputer sebagai alat untuk mengelola dan menganalisis serta menyusun dan membangun suatu sistem basis data dijadikan sebagai alat bantu analisis agar pengambilan keputusan yang akurat dan tepat dalam organisasi dan menjadi lebih terarah. Teknologi dan informasi memiliki peran yang penting dalam memudahkan pengguna mengolah data administrasi tata usaha, pelayanan masyarakat, memberikan informasi bagi pihak yang berkepentingan. Peran teknologi informasi lebih memudahkan pengambilan keputusan dan membantu menyelesaikan pekerjaan dibandingkan dengan cara manual.

Aplikasi Mobile SAMPADE merupakan sistem informasi yang baru di implementasikan dan sebagai salah satu inovasi perkembangan TI yang disediakan untuk memudahkan sekaligus meningkatkan pelayanan kepada Wajib Pajak untuk melaksanakan hak dan pemenuhan kewajiban perpajakan. Keuntungan dari aplikasi ini yaitu mudahnya akses informasi terkait objek pajak, informasi tagihan dan tunggakan, informasi tentang sistem pelaporan pembayaran dan pengumuman pajak daerah. Masyarakat dapat melakukan konsultasi terkait dengan pajak daerah hingga dapat mengunduh peraturan pajak daerah. Perkembangan teknologi untuk pembayaran menggunakan sistem online serta informasi dengan menggunakan aplikasi mobile ini, dapat lebih meningkatkan kemudahan, pelayanan, pembayaran dan pelaporan Wajib Pajak dalam melaksanakan kewajiban perpajakannya. Implementasi sistem ini belum bisa ditentukan tingkat keberhasilannya, dikarenakan masih tergolong sistem baru. Hambatan implementasi sistem berdasarkan teori yang dijelaskan oleh Ramayah dan Zakaria dalam Suyanto, dkk., (2015), bahwa faktor penghambat implementasi sistem teknologi yaitu tantangan pada organisasi, tantangan pada manusia, dan tantangan pada teknologi. Kesuksesan implementasi sistem dapat diukur atau dievaluasi menggunakan model DeLone dan McLean, (2003). Model kesuksesan sistem informasi DeLone dan McLean dapat dilihat pada gambar 1 dan pada paper ini sisi kesuksesan sistem dilihat dari sisi penyelenggara sistem yaitu BP2D. Berdasarkan beberapa informasi di atas dapat asumsikan bahwa implementasi sistem informasi merupakan penerapan suatu sistem yang merupakan rangkaian proses untuk menerapkan sistem informasi yang baru ke dalam operasi pada sistem yang telah ada, dan TI sebagai alat pendukung sistem informasi yang paling canggih saat ini. 


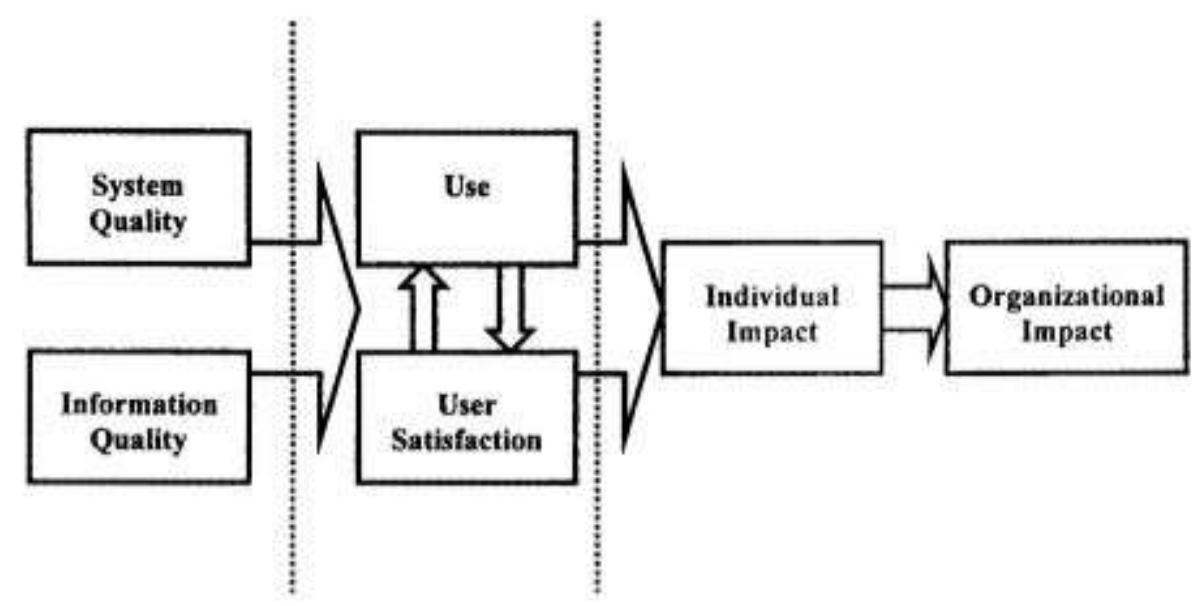

Gambar 1. Model kesuksesan sistem informasi

Sumber: DeLone dan McLean, 2003

\section{Metode Penelitian}

Jenis penelitian yang digunakan di dalam penelitian ini yaitu jenis penelitian kualitatif dengan pendekatan deskriptif. Penelitian Kualitatif adalah penelitian interdisipliner dan kadang melintasi bidang kedisiplinan seperti sosial humaniora dan ilmu sosial dan fisik. Penelitan Kualitatif berkomitmen pada perspektif naturalistik dan pemahaman intepretatif dari pengalaman manusia (Nelson, dkk., 1992). Pengertian deskriptif pada penelitian ini menurut Moleong (2012) adalah penelitian yang bermaksud untuk memahami fenomena mengenai pemanfaatan TI dalam pelayanan pajak daerah, tentang apa yang dialami oleh subjek penelitian contohnya seperti implementasi sistem baru mengenai keunggulan dan apa saja hambatan yang melingkupi kegiatan implementasi tersebut. Penelitian deskriptif dilakukan untuk memberikan gejala-gejala dan fakta-fakta atau kejadian secara sistematis dan akurat (Sutanto dalam Leliya dan Afiyah, 2016). Penyampaian hasil amatan dengan cara deskripsi dalam bentuk katakata dan bahasa, pada suatu konteks khusus yang alamiah dan dengan memanfaatkan berbagai metode ilmiah terkait dengan kesuksesan sistem informasi. Penelitian kualitatif berfokus pada hasil penelitian dan menjadi dasar dalam pemecahan masalah. Penelitian ini memiliki fokus penelitian, yaitu mengetahui, mendeskripsikan, dan menganalisis implementasi sistem informasi Aplikasi Mobile Pajak Daerah (SAMPADE).

Penelitian ini juga bertujuan mengetahui kelebihan sistem sebagai kompetensi khusus yang memberikan keunggulan komparatif bagi organisasi pemerintah pemungut pajak daerah dalam melayani wajib pajak. Kekuatan organisasi sebagai pelayan masyarakat harus dipertahankan agar dapat terus berdiri dan unggul dalam bidang yang dikuasai dalam hal ini adalah pemanfaatan TI sebagai keunggulan kompetitif untuk pelayanan pajak. Selain keunggulan juga selanjutnya perlu diketahui kekurangan yang merupakan keterbatasan atau kekurangan penyelenggara sistem yang secara serius dapat menghambat kinerja efektif organisasi.

Pada penelitian ini menggunakan teknik pengumpulan data primer dengan mewawancara narasumber yaitu orang-orang yang paling mengetahui penerapan sistem informasi ini. Observasi juga dilaksanakan dengan mengadakan pengamatan langsung jalannya sistem yang melayani wajib pajak dan mencatat hal-hal yang diperlukan dan berkaitan dengan fokus penelitian. Dokumentasi yang digunakan dalam penelitian ini meliputi Standart Operational Procedure (SOP) terkait dengan pelaksanaan dan prosedur operasional SAMPADE. Keabsahan data (credibility) yang digunakan dalam penelitian ini untuk mendapatkan dan memeriksa derajat kepercayaan data digunakan teknik pemeriksaan triangulasi yaitu triangulasi sumber. 


\section{Hasil dan Pembahasan}

Gambaran umum implementasi sistem secara ringkas akan dijelaskan berikut. Sistem informasi ini juga digunakan untuk meningkatkan Pendapatan Asli Daerah (PAD), pemerintah Kota Malang meluncurkan aplikasi sistem aplikasi mobile pajak daerah atau disebut SAMPADE juga dalam rangka meningkatkan target penerimaan pajak. Sistem aplikasi yang digunakan yaitu berupa perangkat lunak berbasis mobile yang digunakan untuk mengetahui dan melakukan pengambilan keputusan terkait dengan pajak daerah Kota Malang. Daerah lain selain kota Malang juga telah menggunakan sistem informasi dalam mengumpulkan informasi tentang perpajakan serta untuk mengelola sistem pajak secara online seperti di kota-kota besar dan beberapa kota kecil. Sistem pajak secara online itu sebagai salah satu upaya untuk mengurangi adanya kebocoran PAD dari sektor pajak restoran, hotel, dan tempat hiburan yang dikelola oleh BP2D Kota Malang. Sistem pajak online yang rapi dan transparan juga sebagai salah satu upaya pemberantasan korupsi dari sektor pajak. Dengan sistem informasi ini, pengguna dalam hal ini wajib pajak tidak bisa memanipulasi besaran pajak yang harus dibayarkan dan ini adalah salah satu formula yang digunakan untuk mengatasi dan merubah sistem yang ada di Kota Malang untuk menjadi lebih baik. Sistem pajak online ini, sangat menguntungkan para pengusaha restoran, hotel, dan tempat hiburan yang ada di Kota Malang, WP akan menggunakan sistem online dalam melaporkan pajaknya. Penyelenggaraan sistem ini tidak lepas dari kebutuhan biaya pengadaan. Pada penganggaran penerapan sistem pelaporan perpajakan ini terdiri dari dua macam kegiatan yaitu anggaran untuk infrastruktur TI dan anggaran operasional. Penyelenggara sistem telah berhasil memetakan kebutuhan implementasi sistem yaitu adanya perencanaan yang jelas untuk pembiayaan dan pengadaan perangkat hardware dan software serta maintenance. Tampilan halaman beranda dalam aplikasi mobile SAMPADE dapat dilihat pada gambar 2. BP2D Kota Malang juga menyiapkan anggaran operasional pelaksanaan yang dialokasikan dalam bentuk kegiatan BP2D pada Anggaran Pendapatan Belanja Daerah (APBD) Kota Malang tiap tahunnya.

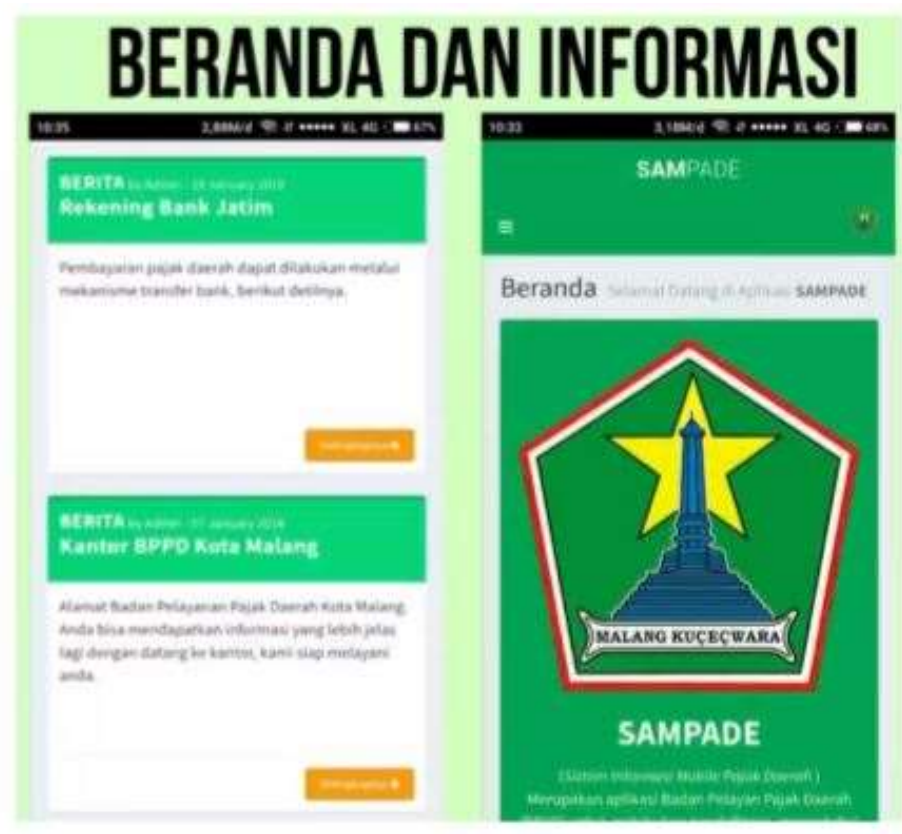

Gambar 2. Tampilan beranda Aplikasi Mobile Sampade

SAMPADE adalah sistem teknologi informasi berbentuk software aplikasi, sistem ini merupakan alat yang memudahkan wajib pajak untuk melaporkan dan mengkonfirmasi pajak daerahnya secara online. Dengan sistem online maka seharusnya tidak ada hambatan WP dalam mengakses informasi perpajakannya di mana pun dan kapan pun. Sistem ini melengkapi sistem $e$-Tax yang sudah berjalan lebih dulu dari tahun 2013 dan BP2D kota Malang harus cepat mengintegrasikannya dengan sistem $e$ - 
Tax agar tidak membingungkan wajib pajak untuk memilih sistem pembayaran dan pelaporan pajak. Penerapan sistem ini merupakan sebuah tindakan yang dilakukan BP2D untuk mencapai tujuannya dan memberikan kemudahan kepada WP, Unsur-unsur penerapan meliputi; 1) Sistem telah dilucurkan secara resmi oleh pemerintah kota Malang, yaitu diluncurkannya pada bulan Mei 2018; 2) Terdapat kelompok target yaitu masyarakat sebagai WP (terutama wajib pajak hotel, restoran, parkir, dan hiburan) yang menjadi sasaran pihak BP2D untuk berpartisipasi dan melakukan kewajiban perpajakannya sesuai dengan ketentuan yang ada, harapannya adalah WP menerima manfaat dari tujuan BP2D menerapkan sistem tersebut; 3) Terdapat pelaksanaan, terkait penerapan pembayaran tentunya adanya organisasi atau perorangan yang bertanggung jawab dalam pengelolaan, pelaksanaan maupun pengawasan dari proses penerapan tersebut. Pihak yang bertanggung jawab diantaranya: Pemerintah Pusat dan Pemerintah Provinsi, Kepala BP2D kota Malang beserta seluruh jajaran, pihak penerima pembayaran dalam hal ini adalah mitra perbankan yaitu PT. Bank Jawa Timur Wilayah Malang serta WP pajak daerah kota Malang; 4) Mewujudkan tata kelola pemerintah yang baik yang dalam hal ini sistem TI membantu mewujudkan pemerintahan yang efektif dengan sistem e-government nya

\subsection{Keberhasilan Sistem}

Kesuksesan penerapan sistem SAMPADE pada BP2D Kota Malang dapat dilihat dari beberapa indikator keberhasilan sistem:

\section{a. Kualitas Sistem}

Sistem SAMPADE merupakan sebuah sistem aplikasi pelaporan berbentuk software, yang merupakan sistem resmi Pemerintah Daerah Kota Malang. Penerimaan pajak daerah terutama berasal dari restoran, hotel, hiburan dan parkir yang pencatatan transaksi dan pelaporan secara online secara resmi telah berjalan secara formal melalui sistem ini.

\section{b. Kualitas Informasi}

Sistem berkualitas yaitu informasi bersumber dari BP2D serta dari pernyataan vendor ahli sistem menyatakan bahwa data yang masuk adalah akurat. Informasi pelaporan sistem langsung tertera pada aplikasi tersebut dalam waktu cepat. Pada aplikasi sistem ini terdapat informasi tambahan yang membantu dalam memberikan informasi yang sesuai kepada WP.

\section{c. Kualitas Pelayanan.}

Dengan informan, kualitas pelayanan SAMPADE merupakan pelayanan sederhana dengan prosedur yang mudah dipahami, cepat dalam memberikan respon, aman, akuntanbel dan informatif serta didukung sarana dan prasarana yang sesuai dan nyaman. Sistem ini berfungsi untuk mencegah hilangnya potensi kecurangan akibat WP maupun petugas pajak tidak transparan terhadap transaksi data.

Keberhasilan sebuah sistem menurut DeLone dan McLean, (2003) yaitu pada tiga dimensi antara lain dimensi kualitas sistem, dimensi kualitas informasi dan dimensi kualitas pelayanan sistem pada BP2D Kota Malang. Peneliti menemukan bahwa: pertama, kualitas sistem sangat sederhana dan memudahkan WP, cukup dengan mengunduh aplikasi tersebut dan langsung mengisi data diri untuk mendaftar maka sistem langsung bisa digunakan, khususnya untuk WP yang sudah mendaftar sebelumnya ke BP2D. Kedua, kualitas informasi harus mengandung unsur kelengkapan, relevan,dan akurat, dalam temuan penelitian ini informasi sistem SAMPADE belum mencakup tiga unsur tersebut. Sistem informasi belum berhasil karena SAMPADE belum mencakup beberapa unsur kualitas sistem, yaitu untuk pembayaran pajak. Pada saat digunakan WP tidak ditemukan fungsi pembayaran pajak tetapi hanya untuk pelaporan. Ketiga, kualitas pelayanan, pelayanan berkualitas harus mengandung unsur kecepatan respon, kesederhanan, jaminan dan empati, dalam hal ini bahwa BP2D telah menerapkan pelayanan menggunakan teknologi informasi seoptimal mungkin melalui aplikasi SAMPADE, namun terjadi serangan pada sistem mengakibatkan sistem tidak dapat digunakan (down) dalam waktu yang cukup lama pada awal penggunaannya, sehingga unsur kecepatan respon, kesederhanan, jaminan dan empati tidak dapat terselenggara. Dari beberapa fakta tersebut peneliti meyakini bahwa implementasi sistem SAMPADE belum berhasil di implementasikan dengan baik. 


\subsection{Keberhasilan Implementasi}

Salah satu keberhasilan untuk mengimplementasikan sistem pelaporan pajak secara online adalah dengan menerapkan sistem yang berkualitas, informasi yang berkualitas, dan kualitas pelayanan. Maka bentuk keberhasilan implementasi sistem secara normal adalah sebagai berikut:

\section{a. Kualitas Sistem}

Kualitas sistem berhubungan dengan kemudahan dalam mengakses sistem oleh pengguna. Sistem SAMPADE dirancang untuk memberikan kemudahan WP, kemudahan tersebut antara lain: 1) Kemudahan untuk digunakan/dioperasikan) 2) Kemudahan kecepatan akses yaitu sistem waktu respon yang singkat.

\section{b. Kualitas Informasi}

Informasi merupakan elemen kunci dalam penerapan sistem, klasifikasi kualitas informasi pada sistem SAMPADE Kota Malang adalah: 1) Lengkap, yaitu informasi yang ditampilkan pada sistem ini sesuai dengan pelayanan. 2) Relevan, yaitu sistem ini diterapkan untuk memenuhi kemajuan teknologi saat ini, selain itu sebagai perwujudan program pemerintah tentang reformasi administrasi perpajakan. 3) Akurat, yaitu ada sistem informasi SAMPADE ini informasi yang ditampilkan adalah akurat karena bersumber dari fenomena-fenomena masyarakat dalam hal pembayaran pajak hotel yang terhutang. 4) Tepat waktu, yaitu sistem ini memiliki tujuan agar wajib pajak kota Malang mendapatkan informasi yang berkualitas dan paling mutakhir dari BP2D.

\section{c. Kualitas Pelayanan}

Kualitas pelayanan sistem pada BP2D Kota Malang diketahui masih belum prima. Fakta membuktikan masih terdapat kekurangan pelayanan sistem antara lain yaitu masih menggunakan cara pembayaran manual dalam melayani Wajib Pajak. Sistem ini juga memiliki kelebihan kualitas pelayanan yang dapat meningkatkan prosedur pelaporan. Unsur kualitas pelayanan sistem SAMPADE: 1) Kecepatan Respon, yaitu sistem ini memberikan fasilitas kepada WP berupa sarana pelaporan dan informasi tentang pajak hotel yang responsif. 2) Jaminan, yaitu mendapatkan jaminan keakuratan dalam pelaporan pajak hotel. 3) Empati, yaitu dengan menggunakan sistem ini dapat memberikan informasi yang sesuai kebutuhan WP seperti mengenai status pelayanan dan pelaporan pajaknya.

Peneliti berpendapat implementasi sistem tidak efektif karena yang menggunakan SAMPADE tidak merata di Kota Malang dan sistem ini dirasa belum cukup efektif pula dalam hal operasional. SAMPADE belum sepenuhnya berhasil karena dari akurasi data transaksi dapat mengalami gangguan atau kesengajaan sehingga merusak atau mengubah data asli tersebut dan dalam keandalan sistem belum mampu melayani kebutuhan pengguna tanpa ada kendala yang dapat mengganggu kenyamanan pengguna.

\subsection{Kelebihan dan Kekurangan SAMPADE}

Keterbatasan atau kekurangan dalam sumber daya, keterampilan dan kapabilitas yang secara serius menghambat kinerja efektif organisasi dalam hal ini BP2D kota Malang. Fasilitas, sumber daya keuangan, kapabilitas manajemen, keterampilan pemasaran, dan citra merek dapat merupakan sumber kelemahan. Terdapat beberapa kekurangannya diantaranya banyak wajib pajak yang belum menggunakan sistem dan merasa belum diwajibkan untuk menggunakannya. BP2D perlu mensosialisasikan sistem ke WP dengan mengadakan pelatihan sistem di area regional kota Malang. BP2D mengalami kendala terhadap wajib pajak yang menggunakan sistem tetapi tidak dioperasikan, hasilnya SAMPADE hanya sebagai aplikasi pajangan di handphone wajib pajak yang digunakan sekali dalam setahun atau tidak digunakan kembali. WP khusus nya pajak hotel lebih banyak menggunakan $e$ Tax daripada menggunakan. WP harus mengikuti alur ketentuan dari BP2D untuk menggunakan aplikasi SAMPADE demi kerahasiaan data wajib pajak. Perkembangan sistem sendiri dalam posisi stagnan, jumlah pengguna sistem ini misalnya untuk WP hotel tidak meningkat atau berkembang dikarenakan penerapan aplikasi SAMPADE hanya sebagai pelaporan, untuk pembayaran tetap menggunakan sistem manual atau menggunakan e-Tax. 
Kelebihan sistem dalam analisis Strength Weakness Opportunity, Threats (SWOT) dijelaskan oleh Rangkuti, (2013) yaitu sebelum adanya sistem online ini WP harus datang ke kantor BP2D untuk mengisi SPTPD, namun dengan adanya aplikasi ini WP dapat mendaftarkan objek pajaknya, melakukan pelaporan serta konfirmasi pembayaran pajak daerah dengan aplikasi mobile tersebut. Hasil pembahasan bahwa implementasi sistem ini memiliki lebih banyak kekurangannya daripada kelebihan. Sistem SAMPADE yang diterapkan oleh BP2D Kota Malang belum berhasil karena kebijakan nya belum efektif atau belum sepenuhnya dapat dikaji, karena Standar Operasionalnya Prosedur (SOP) nya tidak dapat ditunjukkan atau diperoleh di kantor BP2D, jadi perlu mensosialisasikan secara berlanjut ke pengguna sistem/WP.

\subsection{Dukungan Sistem Informasi dalam Mewujudkan Reformasi Administrasi Perpajakan}

Reformasi Administrasi Perpajakan adalah penyempurnaan atau perbaikan kinerja administrasi, baik secara individu, kelompok, maupun kelembagaan agar lebih efisien, ekonomis, dan cepat. Berdasarkan pendapat tersebut maka BP2D sudah menerapkan reformasi administrasi perpajakan seperti contohnya dengan mengeluarkan sistem e-Tax, SAMPADE, e-BPHTB, dan sistem online lainnya, oleh karena itu demi berjalan nya reformasi administrasi perpajakan di Kota Malang, pemerintah Kota Malang serta BP2D Kota Malang menghimbau wajib pajak untuk mengikuti perkembangan teknologi dan sistem informasi sehingga mampu mendorong terwujudnya good governance (tata kelola pemerintahan yang baik). Peluang dan ancaman merupakan faktor-faktor yang datang dari lingkungan eksternal BP2D dapat merugikan seperti dalam kesuksesan pelaksanaan implementasi sistem, mencegah pencapaian sasaran atau merusak strategi yang telah ditetapkan sebelumnya. Peneliti menemukan kecenderungan yang kuat dan menguntungkan bagi pihak BP2D agar mencapai tujuan penerapan sistem yaitu adalah disediakannya sarana dan prasarana yang memadai bagi BP2D untuk menjalankan sistem. Hambatan penerapan sistem pelaporan pajak hotel menggunakan sistem ini berdasarkan teori yang dijelaskan oleh (Rangkuti, 2013) adalah ancaman implementasi sistem. Ancaman adalah faktor lingkungan yang tidak menguntungkan bagi BP2D dan jika tidak diatasi maka akan menjadi hambatan bagi organisasi. Temuan hambatan lainnya pada implementasi sistem pelaporan pajak hotel menggunakan SAMPADE adalah jaringan internet yang tidak stabil, sarana dan prasarana wajib pajak dalam pengoperasian sistem aplikasi diperlukan smartphone berbasis operating system (OS) android yang memadai. Fakta yang ada adalah tidak semua wajib pajak menggunakan smartphone android atau menggunakan yang tidak memadai. Sistem ini wajib diunduh di playstore yang dimana harus smartphone dengan spesifikasi OS yang memadai untuk mengoperasikannya. Penghambat yang lain yaitu kurangnya pengetahuan tentang aplikasi sistem aplikasi SAMPADE, dan terdapat WP yang tidak mengetahui kelebihan dari aplikasi tersebut untuk melaporkan dan memudahkan kewajiban perpajakannya sehingga tidak tertarik dengan aplikasi itu. Sebagian wajib pajak yang sudah mengunduh sistem di playstore digunakan hanya sekali saja, sehingga sistem tersebut tidak digunakan kembali atau diabaikan. Hambatan terakhir yaitu lemahnya keamanan sistem sehingga masih dengan mudah dapat diretas oleh pihak yang tidak bertanggung jawab.

Jika sebuah organisasi menerapkan sistem informasi seharusnya hambatan-hambatan yang menjadikan faktor penghambat sebuah penerapan sistem dapat dikaji kembali dengan berbagai kemungkinan yaitu BP2D sebagai pengelola dan penanggung jawab. BP2D Kota Malang telah berupaya memberikan solusi untuk mengatasi hambatan sistem yang direncanakan dengan strategi yang jelas, bagaimana manfaatnya, dan apakah solusi tersebut tepat sasaran, karena tujuannya memudahkan dalam melakukan evaluasi perbaikan untuk menjadi lebih baik dan terarah, solusi tersebut diantaranya dengan cara melaksanakan pendekatan, sosialisasi dan pengadaan kupon hadiah jalan sehat untuk wajib pajak. Adanya hambatan tersebut membuat tidak sejalannya penerapan sistem sesuai dengan teori yang menyatakan bahwa penerapan sistem merupakan suatu kegiatan mempraktekkan suatu teori, metode, dan hal lain untuk mencapai tujuan tertentu dan untuk suatu kepentingan yang diinginkan oleh organisasi 
melalui analisis dan desain sistem. Hal ini peneliti berpendapat bahwa sistem pelaporan SAMPADE telah diterapkan akan tetapi masih belum tercapai tujuannya.

Komputer untuk server database yang mendukung sistem ini contohnya adalah sistem komputer yang berskala menengah dan sistem komputer yang bermainframe besar. Komputer yang memiliki mainframe besar berarti penerapan sistem yang harus menerapkan teknologi informasi yang mengacu kepada kelas tertinggi dari komputer yang terdiri dari super komputer. Infrastruktur seperti super komputer di BP2D belum memadai untuk aktivitas berat atau pemilihan spesifikasi yang tidak terlalu baik, maka implementasi sistem di BP2D masih belum berjalan lancar dikarenakan masih belum tepatnya infrastruktur yang digunakan dan tidak adanya prediksi bahwa suatu saat akan terjadi bottle neck penggunaan sistem, hal ini akan menjadikan hambatan kembali sehingga WP yang melaporkan dan membayar pajaknya akan kembali melakukan aktivitas perpajaknnya secara manual karena dianggap lebih praktis daripada menunggu sistem yang down untuk dapat aktif kembali.

\section{Kesimpulan}

Reformasi administrasi perpajakan di BP2D Kota Malang adalah penerapan moderenisasi administrasi perpajakan dengan teknologi dan informasi. Modernisasi administrasi perpajakan bertujuan untuk menerapkan Good Governance dan pelayanan yang prima kepada wajib pajak. Dari hasil peneltian yang telah dilakukan pada BP2D Kota Malang, sistem ini dapat mendukung pemerintahan yang bersih karena sistem perpajakan yang transparan, akuntabel dan akurat berbasis pemanfaatan teknologi informasi dan komunikasi sehingga mampu mendorong terwujudnya good governance (tata kelola pemerintahan yang baik).

Secara Kualitas, sistem ini membantu memudahkan wajib pajak khususnya WP hotel dalam kewajiban perpajakannya, namun dari sistem informasi belum berhasil karena sistem masih mengalami kendala yaitu kesalahan dalam pengiriman data dalam proses pengoperasian. Kualitas pelayanan sistem mampu membantu wajib pajak dalam pelaporan pajaknya. Sistem ini merupakan sistem online maka dalam hal maintenance masih banyak masalah-masalah yang ditemukan antara lain masih adanya bug dan memerlukan tih ahli untuk memperbaiki aplikasi tersebut. Kegagalan penyediaan tim ahli TI dapat dilihat contohnya seperti saat server aplikasi diserang oleh peretas sistem secara mudah.

Hambatan dalam pelaksanaan SAMPADE yaitu WP mengabaikan aplikasi dan akhirnya memilih untuk melaporkan pajak daerahnya secara konvensional karena menganggap masih belum berjalan sempurna. Dari sisi penyelenggara sistem masih ditemukan adanya ketidakrapian perencanaan sistem yaitu sulitnya Standar Operational Procedure (SOP) untuk ditemukan pada sistem. Ketidak tersediaan SOP dapat mempersulit posisi ahli sistem pada keadaan jika terjadi gangguan sistem. Ketidakadaan SOP menyebabkan tidak jelasnya pedoman penggunaan sistem akhirnya menambah kelemahan dari sistem ini yaitu wajib pajak masih banyak belum mengetahui tentang aplikasi mobile SAMPADE baik cara maupun panduan penggunaannya. Kelebihan pada implementasi sistem pelaporan pajak daerah menggunakan SAMPADE yaitu memudahkan wajib pajak dalam proses pelaporan pajaknya sehingga menjadi ringkas dan praktis. Sistem ini juga mendapat dukungan dari ketersediaan hardware dan software yang cukup meskipun belum memadai untuk menjalankan sistem SAMPADE serta adanya server database dan komputer serta koneksi internet yang lancar.

Rekomendasi dari hasil penelitian ini adalah pihak BP2D melakukan analisis sistem ulang terhadap sistem yang berjalan, dari hasil analisis dapat dilakukan desain ulang sistem yang lebih baik performanya. Rekomendasi berikutnya adalah perlu adanya peningkatan penerapan tata kelola sistem informasi yang standar seperti COBIT dan ITIL untuk meminimalkan adanya dampak gangguan sistem pada BP2D Kota Malang. Rekomendasi lain adalah paper in idapat digunakan sebagai referensi bagi penelitian selanjutnya yang akan mengukur kesuksesan sistem informasi dari sisi pengguna sistem yaitu WP. 


\section{Daftar Pustaka}

DeLone, W. H. dan McLean, E. R. (2003). The DeLone and McLean model of information systems success: A ten-year update. Journal of Management Information Systems. https://doi.org/10.1080/07421222.2003.11045748

Leliya dan Afiyah, F. (2016). Efektivitas Sistem Pembayaran Pajak Daerah Online Dalam Peningkatan Pendapatan Daerah Kota Cirebon Leliya. Jurnal AL-Mustashfa.

Moleong, L. J. (2012). Metodologi Penelitian Kualitatif. Bandung : PT Remaja Rosdakarya

Muttaqien dan Kusmayadi, E.. (2009). Dasar-Dasar Teknologi Informasi. Jakarta: Universitas Terbuka

Nelson, C., Treichler, P, dan Grossberg, L. (1992) 'Cultural studies: an introduction', in Grossberg, L., Nelson, C., and Treichler, P. (eds) Cultural Studies, New York, Routledge. (pp1-16).

Rangkuti, F. (2013). Teknik Membedah Kasus Bisnis Analisis SWOT Cara Perhitungan Bobot, Rating, dan OCAI. In PT. Gramedia Pustaka Utama. Jakarta.

Suyanto, S., Taufiq, H., dan Indiati, I. (2016). Faktor Penghambat Implementasi Sistem Informasi Manajemen Rumah Sakit di RSUD Blambangan Banyuwangi. Jurnal Kedokteran Brawijaya. https://doi.org/10.21776/ub.jkb.2015.028.02.5

Giap, Y. C. (2011). Pengantar Teknologi Informasi. Jakarta: Mitra Wacana Media 